\title{
New records of bats (Chiroptera) from Santa Cruz province (Argentina) and the southernmost record of Lasiurus varius (Poeppig, 1835) for Argentina
}

\author{
M. Mónica Díaz, ${ }^{1,2,3}$ Alejandro Valenzuela, ${ }^{2,4,5}$ Silvina Sturzenbaum, ${ }^{6}$ Rubén M. Barquez ${ }^{1,2}$ \\ 1 Programa de Investigaciones de Biodiversidad Argentina, Programa de Conservación de los Murciélagos de Argentina, Facultad de Ciencias \\ Naturales e IML. Universidad Nacional de Tucumán. Miguel Lillo 205, 4000, San Miguel de Tucumán, Tucumán, Argentina. 2 Consejo Nacional \\ de Investigaciones Científicas y Técnicas, Argentina. 3 Fundación Miguel Lillo, Miguel Lillo 251, 4000, San Miguel de Tucumán, Tucumán, \\ Argentina. 4 Dirección Regional Patagonia Austral, Administración de Parques Nacionales, San Martín 1395, 9410, Ushuaia, Tierra del Fuego, \\ Argentina. 5 Instituto de Ciencias Polares, Ambiente y Recursos Naturales, Universidad Nacional de Tierra del Fuego, AV. Los Ñires 2382, 9410 , \\ Ushuaia, Tierra del Fuego, Argentina. 6 Parque Nacional Los Glaciares, Administración de Parques Nacionales, Av. Del Libertador 1302, 9405, El \\ Calafate, Santa Cruz, Argentina. \\ Corresponding author: M. Mónica Díaz, mmonicadiaz@yahoo.com.ar
}

\begin{abstract}
Here, we report new records for the distribution in Argentina of 3 bat species from the family Vespertilionidae: Lasiurus varius (Poeppig, 1835), Histiotus magellanicus (Philippi, 1866), and Myotis chiloensis (Waterhouse, 1838). The range of $L$. varius is extended by more than $800 \mathrm{~km}$ south of the previous known limit, representing the southernmost known occurrence for the species in Argentina. The new information for M. chiloensis fills a previous existing gap between records known from Chubut and Tierra del Fuego. Similarly, the new record of H. magellanicus also completes its known distribution in the Santa Cruz province.
\end{abstract}

\section{Key words}

Patagonia; Santa Cruz; Vespertilionidae.

Academic editor: Diego Astúa | Received 21 September 2016 | Accepted 30 June 2017 | Published 11 September 2017

Citation: Díaz MM, Valenzuela A, Sturzenbaum S, Barquez RM (2017) New records of bats (Chiroptera) from Santa Cruz province (Argentina) and the southernmost record of Lasiurus varius (Poeppig, 1835) for Argentina. Check List 13 (5): 397-401. https://doi.org/10.15560/13.5.397

\section{Introduction}

Currently, 65 species of bats are known to occur in Argentina (Díaz et al. 2016), but this diversity declines abruptly in the Patagonian region, south of $38^{\circ} \mathrm{S}$, by approximately 84\% (Barquez et al. 1999, 2013). Patagonia is the southernmost region of South America and, in Argentina, extends south from the southern part of Buenos Aires province and includes the provinces of Neuquén, Río Negro, Chubut, Santa Cruz, and Tierra del Fuego (Coronato et al. 2008). In particular, the bat fauna in Santa Cruz is the least known among these Patagonian provinces, and only 3 species of 2 families in a few localities have been recorded (Barquez et al. 1999, 2013). The majority of the previous records come from casual collections and even though they are scarce, they were still important given their relevance for understanding poorly known species that are unique to the region (Barquez et al. 1999, 2013). To date, the only bat species known for Santa Cruz province are Histiotus magellanicus (Philippi, 1866), Histiotus montanus (Philippi \& Landbeck, 1861) 


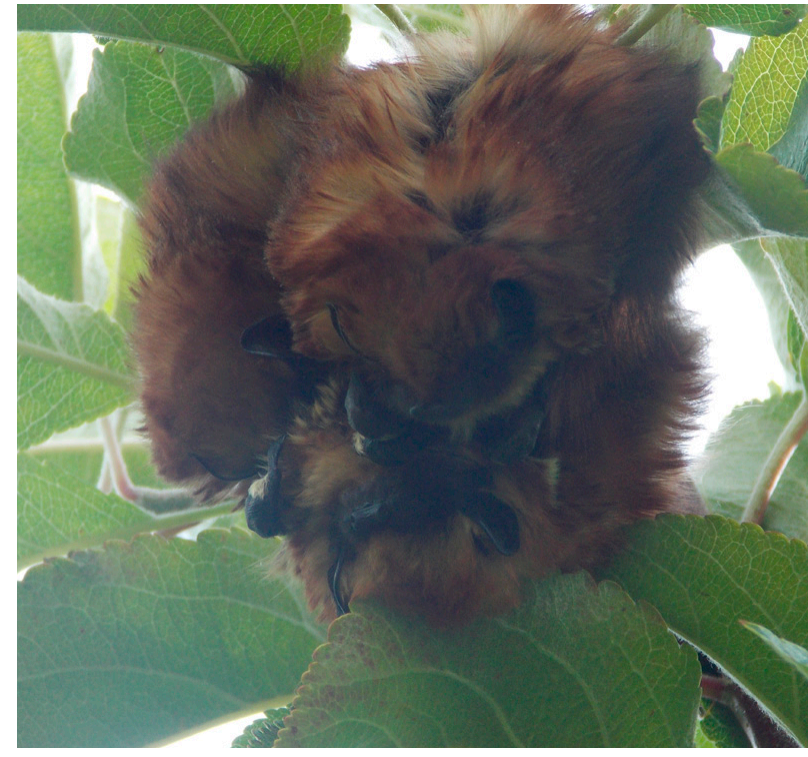

Figure 1. Specimens of Lasiurus varius in an apple tree (Malus domestica) from National Park Los Glaciares, Santa Cruz province. Photograph used with permission of Eduardo Arriaga.

(Vespertilionidae), and Tadarida brasiliensis (I. Geoffroy St.-Hilaire, 1824) (Molossidae) (Barquez et al. 1999, Barquez and Díaz 2009, Barquez et al. 2013).

The objective of this paper is document new records for 3 species of bats (family Vespertilionidae) from the province of Santa Cruz. All 3 species were recorded in the National Park Los Glaciares.

\section{Methods}

The National Park Los Glaciares has an area of 726,927 ha and is located along the province's western border with Chile. The park is a state-owned unit of the Argentine National System of Protected Areas. It was created in 1937 and declared a World Heritage Site by UNESCO in 1981 (APN 1997). Inside the park 2 main habitat types occur: the Andean-Patagonian forest and the Patagonian Steppe (APN 1997).

Park staff found dead bat specimens at 3 different localities. These were collected and sent for identification to the Colección Mamíferos Lillo (CML), Universidad Nacional de Tucumán, where they are now deposited. The specimens examined are as follows: Histiotus magellanicus (1): Parque Nacional Los Glaciares, zona sur, seccional Lago Roca, 50³0'33.6" S, 072 45'39.4" W, $191 \mathrm{~m}$ elev., 1 (CML 10172, female, collected 20 January 2014 by E. Arriaga). Lasiurus varius (1): Parque Nacional Los Glaciares, Península Onelli, cercanías del Arroyo Heim, 5006'35.8" S, 073¹7'36.1" W, 197 m elev., 1 (CML 10173, sex not determined, collected in 2007 by E. Daher). Additional records: Parque Nacional Los Glaciares (Fig. 1: photo of 4 specimens taken by E. Arriaga). Myotis chiloensis (2): Parque Nacional Los Glaciares, zona sur, seccional Lago Roca, 50³0'33.6" S, 07245'39.4" W, 191 m elev., 1 (CML 10175, sex not determined, collected April 2013 by E. Arriaga); Parque
Nacional Los Glaciares, zona sur, zona de minitrekking, Glaciar Moreno, 50³6'52.9" S, 072 55'33.6" W, 273 m elev., 1 (CML 10174, male, collected by B. Roil, date unknown).

\section{Results}

Previous records of bat from Santa Cruz province are scarce (Appendix Table A1). Histiotus montanus was known from 4 localities in the province, while $H$. magellanicus was recorded at only 1; Tadarida brasiliensis was known from 2 localities (Barquez et al. 1999, 2013, Barquez and Díaz 2009, Zapata et al. 2015).

Histiotus magellanicus (Philippi, 1866) is a mediumsized bat with forearm length 44.6-48.7 mm (Giménez et al. 2012). Dorsal coloration is dark brown; ventrally, the tips of hairs are yellowish, strongly contrasting with the bases; all membranes and ears are dark brown; ears are well separated and without any trace of a connecting band; the tragus is well developed, slender, and almost one-half the length of the ear, broad at the base and very narrow at the tip (Barquez et al. 1999, Barquez and Díaz 2009, Giménez et al. 2012, Díaz et al. 2016). The skull and teeth are similar to those of other species in the genus; the greatest length of skull was reported 17.8 $\mathrm{mm}$, and breadth of braincase $8.4 \mathrm{~mm}$; the zygomatic arch has a strongly developed postorbital process of the jugal (Barquez et al. 1999). Distribution of this species is restricted to the southern portion of Argentina and Chile

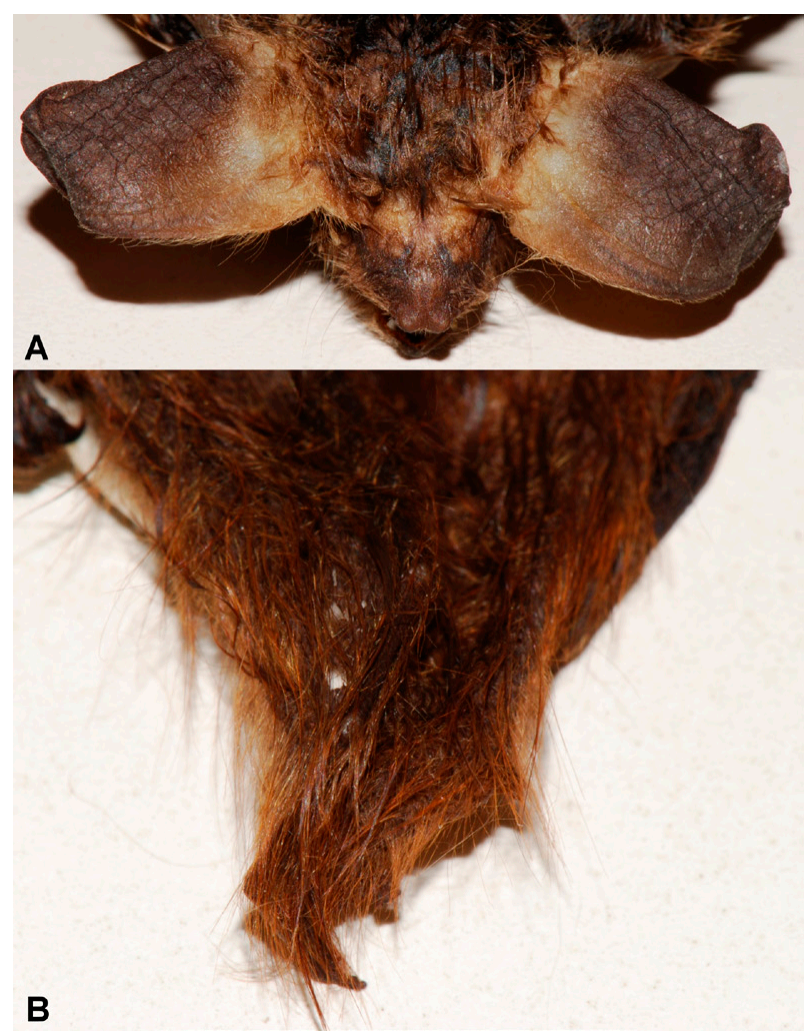

Figure 2. A. Ears of Histiotus magellanicus (CML 10172) from Parque Nacional Los Glaciares, zona sur, seccional Lago Roca. B. Uropatagium of Lasiurus varius (CML 10173) from Parque Nacional Los Glaciares, Península Onelli, cercanías del Arroyo Heim. 


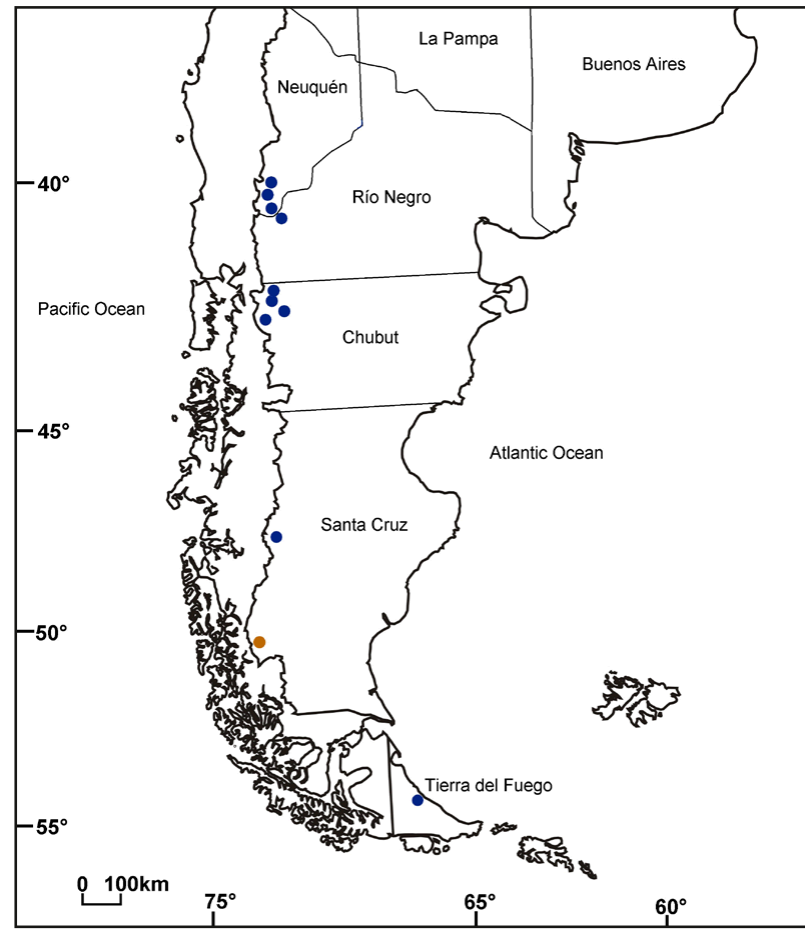

Figure 3. Distribution of Histiotus magellanicus. The blue dots show the known distribution of this species, and the orange dot indicates the new locality added in this study, Los Glaciares National Park, Santa Cruz province.

(Díaz et al. 2016). The recorded specimen has the coloration described above; the most diagnostic characters are the dark and well separated ears (Fig. 2a); the forearm in this specimen is $45.98 \mathrm{~mm}$. In Argentina, it was recorded in 5 provinces (Fig. 3): Neuquén, Río Negro, Chubut, Santa Cruz, and Tierra del Fuego (Mares et al. 1995, Barquez et al. 1999, 2013, Barquez and Díaz 2009, Giménez et al. 2012). The specimen cited by Giménez et al. (2012) as H. magellanicus, also from Parque Nacional Los Glaciares, was later identified in Barquez et al. (2013) as H. montanus. In this way, our record represents the second known of $H$. magellanicus for Santa Cruz, and its distribution is extended for about $300 \mathrm{~km}$ to the south, within this province (Fig. 3). The habitat where this specimen was found constitutes a mosaic of grass steppe with patches of forest (Nothofagus pumilio and N. antarctica); it was found dead on a trunk of $N$. pumilio approximately $50 \mathrm{~cm}$ above the ground.

Lasiurus varius (Poeppig, 1835) is a medium-sized species with forearm length 39.9-42.1 mm (Barquez et al. 1999). Coloration is deep reddish without frosting appearance; dorsal hairs long; ears, markedly separated, black, small, and rounded; uropatagium with long hairs extended beyond the trailing edge (Barquez et al. 1999, Galaz and Yáñez 2006, Gardner and Handley 2008, Galaz et al. 2009). Greatest length of skull was reported 12.8-13.4 $\mathrm{mm}$, and the breadth of braincase 7.5-8.0; the rostrum is short and wide; the nasals and anterior portion of the palate are strongly invaginated so that the incisors of each side are separated by a wide gap (Barquez et al. 1999); the sagittal crest is normally reduced; the

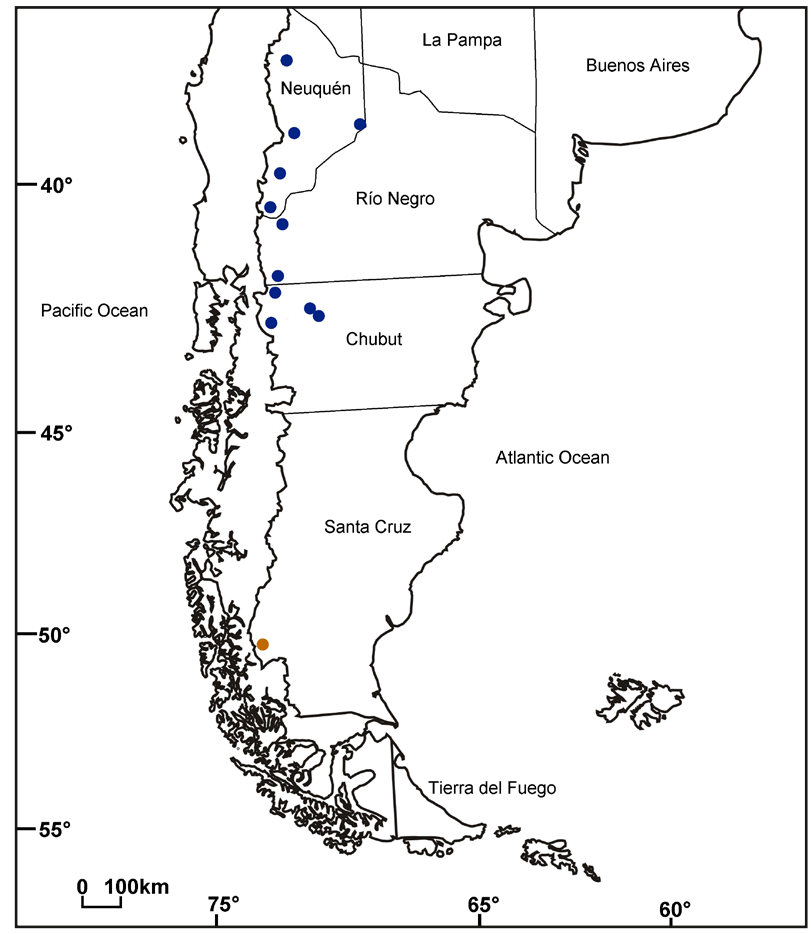

Figure 4. Distribution of Lasiurus varius. The blue dots show the known distribution of this species, and the orange dot indicates the new locality added in this study, Los Glaciares National Park, Santa Cruz province.

lambdoid crests are slightly developed and the paraoccipital process is small but sharp; zygomatic arches thin (Barquez et al., 1999). Upper incisors triangular, canines long and sharply pointed; P1 small and displaced to the lingual side of the toothrow; P2 well developed and unicuspidate; M1 and M2 well developed; the cusps form a "W"; M3 has only 2 commissures; the lower inner incisors are trilobed, while the others are bilobed; p1 small, $\mathrm{p} 2$ more than twice as large as $\mathrm{p} 1$; in $\mathrm{m} 1$ and 2 the trigonid is about the same size as the talonid; in $\mathrm{m} 3$ the talonid is much larger than the trigonid (Barquez et al. 1999). The examined specimen has a deep red coloration and hairs on the uropatagium are extended beyond the edge (Fig. 2b); the forearm is $40.68 \mathrm{~mm}$. It is known from central and southern Chile and southern Argentina (Barquez et al. 1999, 2013). In Argentina, it has only been recorded in 3 provinces, Neuquén, Río Negro, and Chubut (Barquez and Díaz 2009, Barquez et al. 2013, Udrizar Sauthier et al. 2013), and the southernmost known record in Argentina was previously from Chubut province (Parque Nacional Los Alerces, sendero a Cascada Los Alerces, Futaleufú Department, $42^{\circ} 50^{\prime} \mathrm{S}, 071^{\circ} 52^{\prime} \mathrm{W}$ ) (Fig. 4). Although the actual distribution of this species probably includes Tierra del Fuego, its presence in that portion of the country is based solely on the comments made by Dabbene (1902), but no voucher specimens have ever been collected. Dabbene (1902) mentioned Atalapha borealis from Ushuaia (Tierra del Fuego, Argentina) indicating that probably this species was accidentally introduced by ship. Later, based on this comment, Gardner and Handley (2008) considered the presence of Lasiurus varius in Tierra del 


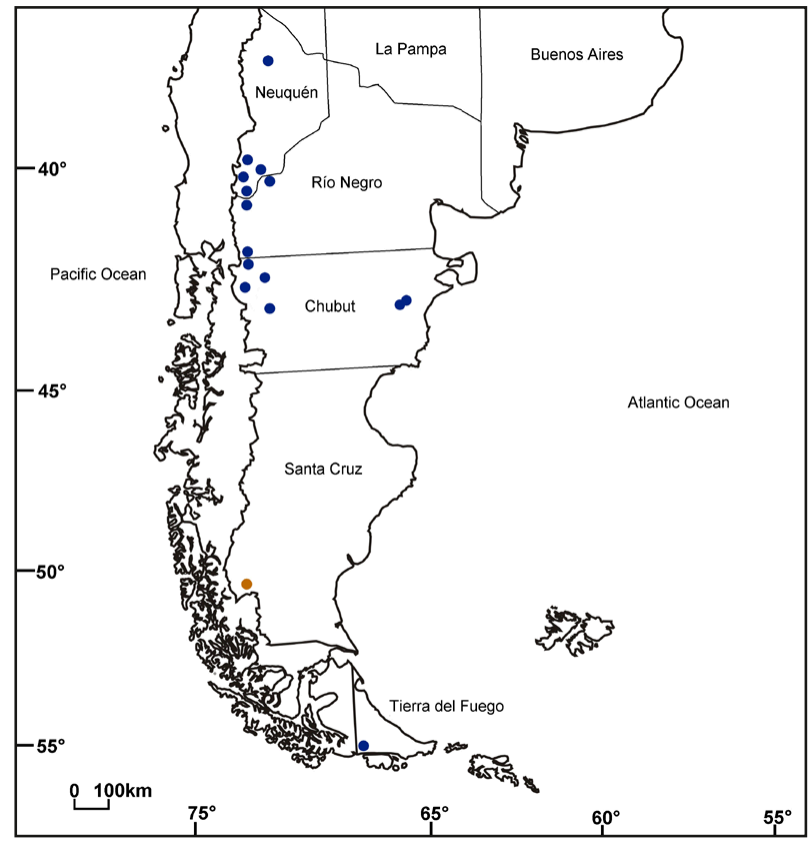

Figure 5. Distribution of Myotis chiloensis. The blue dots show the known distribution of this species, and the orange dot indicates the new locality added in this study, Los Glaciares National Park, Santa Cruz province.

Fuego (Argentina). Therefore, the record here mentioned extends the distribution of $L$. varius more than $800 \mathrm{~km}$ southward (Fig. 4). This specimen was found dead on the ground in an area of Patagonian forest dominated by Nothofagus pumilio, N. betuloides, and Drymis winteri. In addition, 4 specimens were photographed roosting together in the National Park Los Glaciares in the garden of a house in an apple tree (Malus domestica Rosaceae); the deep red coloration, and long and no frosted hairs are indication that these animals belong to the species Lasiurus varius (Fig. 1).

Myotis chiloensis (Waterhouse, 1838) is a small species, with forearm length reported between 37.0 and 40.1 $\mathrm{mm}$; body pelage color varies according to the environment where they live, but the argentine populations are mainly coffee brown, with dorsal hairs bicolored with tips paler than bases. The posterior border of the uropatagium is not white as in M. levis and lacks a fringe of hairs. The skull is robust; with a globose braincase, rostrum elongated, and sagittal crest present but low; the greatest length of skull reported was $14.4 \mathrm{~mm}$ and breadth of braincase $7.1 \mathrm{~mm}$ (Barquez et al. 1999, Ossa and Rodríguez-San Pedro 2015). The examined specimens have the typical coloration of the species, an uropatagium that lacks a fringe of hairs, and the forearm lengths are 38.4 and $40.6 \mathrm{~mm}$. This species is distributed only in Chile and Argentina. In Argentina, it is found in Neuquén, Río Negro, Chubut, and Tierra del Fuego (Barquez and Díaz 2009, Barquez et al. 2013, Udrizar Sauthier et al. 2013, Ossa and Rodríguez-San Pedro 2015). The new records cited in this study helps fill the gap between the records from Chubut and Tierra del Fuego (Fig. 5). The first specimen was found in the same habitat as H. magel- lanicus, a mosaic of grass steppe with patches of forest (Nothofagus pumilio and N. antarctica), while the second one was found dead on a trail in a similar habitat than that for Lasiurus varius, Patagonian forest dominated by Nothofagus pumilio, N. betuloides, and Drymis winteri.

\section{Discussion}

The bat fauna of Patagonia still has not yet been well studied by mammalogists, resulting in the fact that various aspects of its species (e.g., ecology and distribution) are poorly known. Indeed, knowledge of the current distribution of species is based mainly on information obtained from occasional or incidental collections, such as those reported here (Barquez et al. 2013).

The new information added here confirms our previous statement that the southern distribution limits of these species are further south than previously thought. We still need to confirm the presence of species in specific areas and to collect more information on the use of habitat by these species, to determine whether they are adapted to the severity of Patagonia's climate, if they migrate, or if they have any kind of displacement, something that is not known in Argentina. From diverse studies in Patagonia, we also have observed intraspecific morphological differences in coloration of several individuals of the same species from a same region, suggesting the need of conducting more field research, including the collecting of more specimens as well as molecular studies, to determine why and how these differences occur.

Finally, this study adds 2 new species to the bat fauna of Santa Cruz province, increasing the number of species to 5, extending the southern distribution of Lasiurus varius, and filling distributional gaps of $H$. magellanicus and M. chiloensis in Patagonia. Additionally, it is important to emphasize the importance of the protected areas in general, and the National Park Los Glaciares in particular, not only for the conservation of land, ecosystems and species, but also for its contribution to the research and knowledge of the Patagonian fauna.

\section{Acknowledgements}

We thank to the staff of Los Glaciares National Park that helps with the specimens' collection.

\section{Authors' Contributions}

SS helped collect the specimens; AV and SS sent the specimens to the Colección Mamíferos Lillo; MMD and $\mathrm{RMB}$ reviewed and identified the specimens at the Colección Mamíferos Lillo, AV, MMD, RMB wrote the text. MMD draws the map.

\section{References}

APN (1997) Plan preliminar de Manejo del Parque Nacional Los Glaciares. Administración de Parques Nacionales, El Calafate, Argentina, 
115 pp. [Technical report].

Barquez RM, Díaz MM (2009) Clave de Identificación de los Murciélagos de Argentina. Publicación del PCMA (Programa de Conservación de los Murciélagos de Argentina), Tucumán, 80 pp.

Barquez RM, Mares MA, Braun JK (1999) The bats of Argentina. Special publications, Museum of Texas Tech University 42: 1-275.

Barquez RM, Carbajal MN, Failla M, Díaz MM (2013) New distributional records for bats of the Argentine Patagonia and the southernmost known record for a molossid bat in the world. Mammalia 77: 119-126. https://doi.org/10.1515/mammalia-2012-0053

Coronato AMJ, Coronato F, Mazzoni E, Vázquez M (2008) The Physical Geography of Patagonia and Tierra del Fuego. In: Rabassa J (Ed.) The Late Cenozoic of Patagonia and Tierra del Fuego, Volume 11 (Developments in Quaternary Science), 1st Edition. Elsevier Science, Oxford, 13-56.

Dabbene R (1902) Fauna magellanica. Mamíferos y Aves de la Tierra del Fuego é islas adyacentes. Anales del Museo Nacional de Buenos Aires 3: 341-409.

Díaz MM, Solari S, Aguirre LF, Aguiar L, Barquez RM (2016) Clave de Identificación de los Murciélagos de Sudamérica/Chave de Indentificação dos Morcegos da América do Sul. Publicación Especial Nro 2 PCMA (Programa de Conservación de los Murciélagos de Argentina). Editorial Magna Publicaciones, Tucumán, 160 pp.

Galaz JL, Yáñez Y (2006) Los Murcielagos de Chile: Guia para su Reconocimiento. Centro de Ecología Aplicada, Santiago, 80 pp.

Galaz JL, Yañez Y, Gantz A, Martinez DR (2009) Orden Chiroptera. In: Muñoz-Pedreros A, Yañez J (Eds) Mamiferos de Chile. CEA Ediciones, Valdivia, 67-89.

Gardner AL Handley, CO Jr (2008) Genus Lasiurus Gray, 1831.In: Gardner AL (Ed.) Mammals of South America. Volume 1. Marsu- pials, Xenarthrans, Shrews, and BAts. University of Chicago Press, Chicago, 457-468.

Giménez AL, Giannini NP, Schiaffini MI, Martin GM (2012) New records of the rare Histiotus magellanicus (Chiroptera, Vespertilionidae) and other bats from central Patagonia, Argentina. Mastozoología Neotropical 19: 213-224.

Mares MA, Barquez RM, Braun JK (1995) Distribution and ecology of some Argentine bats (Mammalia). Annals of Carnegie Museum 64:219-237.

Ossa G, Rodríguez-San Pedro A (2015) Myotis chiloensis (Chiroptera: Vespertilionidae). Mammalian Species 47 (922): 51-56. https://doi. org/10.1093/mspecies/sev005

Philippi RA (1866) Ueber ein paar neue Chilenische Säugethiere. Archiv für Naturgeschichte 32 (1): 113-117.

Poeppig E (1835) Reise in Chile, Peru und auf dem Amazonenstrome während der Jahre 1827-1832. 1: 464 pp.

Udrizar Sauthier DE, Teta P, Formoso AE, Bernardis A, Wallave P, Pardiñas UFJ (2013) Bats at the end of the world: new distributional data and fossil records from Patagonia, Argentina. Mammalia 77 (3): 307-315. https://doi.org/10.1515/mammalia-2012-0085

Waterhouse GR (1838) The Zoology of the Voyage on the H.M.S. Beagle under the Command of Captain Fitzroy, R.N. During the Years 1832 to 1836. Part II: Mammalia (Darwin C, Ed.) Smith, Elder \& Co., London, 97 pp, 35 pls.

Zapata SC, Procopio DE, Morgenthaler E, Travaini A (2015) Second record of Tadarida brasiliensis (I. Geoffroy St.-Hilaire, 1824) (Chiroptera, Molossidae) in Santa Cruz province, Argentina. Check List 11 (6): 1783. https://doi.org/10.15560/11.6.1783

\section{Appendix}

Table A1. Recorded localities in Santa Cruz province, Argentina. Localities from Santa Cruz province cited by Udrizar Sauthier et al. (2013) are not included here because they considered $H$. magellanicus as a synonym of $H$. montanus, so the species cannot be discriminated.

\begin{tabular}{lllccc}
\hline Species & Department & Locality & Latitude (S) & Longitude (W) & Reference \\
\hline Histiotus magellanicus & Río Chico & Lago Belgrano, Parque Nacional Perito Moreno & $47^{\circ} 48^{\prime} 53.3^{\prime \prime}$ & $072^{\circ} 13^{\prime} 39.1^{\prime \prime}$ & Barquez et al. (2013) \\
Histiotus montanus & Corpen Aiken & Laguna Grande & $49^{\circ} 30^{\prime} 23.0^{\prime \prime}$ & $070^{\circ} 09^{\prime} 38.1^{\prime \prime}$ & Barquez et al. (1999) \\
Histiotus montanus & Güer Aike & Punta Loyola, S. Patagonia & $51^{\circ} 36^{\prime} 44.4^{\prime \prime}$ & $069^{\circ} 00^{\prime} 11.6^{\prime \prime}$ & Barquez et al. (1999) \\
Histiotus montanus & Lago Argentino & Parque Nacional Los Glaciares: Seccional Río Mitre & $50^{\circ} 27^{\prime} 53.2^{\prime \prime}$ & $072^{\circ} 48^{\prime} 4.4^{\prime \prime}$ & Barquez et al. (2013) \\
Histiotus montanus & Magallanes & San Julián & $49^{\circ} 18^{\prime} 23.8^{\prime \prime}$ & $067^{\circ} 43^{\prime} 44.1^{\prime \prime}$ & Barquez et al. (1999) \\
Tadarida brasiliensis & Güer Aiken & Faro Cabo Vírgenes, instalaciones de la Armada & $52^{\circ} 19^{\prime} 58.1^{\prime \prime}$ & $068^{\circ} 21^{\prime} 22.7^{\prime \prime}$ & Barquez et al. (2013) \\
Tadarida brasiliensis & Deseado & Puerto Deseado & $47^{\circ} 45^{\prime} 15^{\prime \prime}$ & $065^{\circ} 54^{\prime} 01^{\prime \prime}$ & $Z_{\text {Zapata et al. (2015) }}$ \\
\hline
\end{tabular}

